\title{
ALKALINE PROTEASE FROM A NEW HALOTOLERANT ALKALIPHILIC Bacillus agaradhaerens STRAIN AK-R ISOLATED FROM EGYPTIAN SODA LAKES
}

\author{
PROTEASE ALCALINA DE UMA NOVA ESTIRPE AK-R HALOTOLERANTE E \\ ALCALÓFILA DE Bacillus agaradhaerens ISOLADA A PARTIR DOS LAGOS \\ ALCALINOS EGÍPCIOS
}

\author{
Abdelnasser S. S. IBRAHIM ${ }^{1,2 *}$; Ali A. AL-SALAMAH ${ }^{1}$; Yahya B. ELBADAWI ${ }^{1}$; \\ Mohamed A. EL-TAYEB ${ }^{1}$; Khalid ALMAARY ${ }^{1}$; Atif A. ELAGIB ${ }^{3,4}$ \\ 1. Department of Botany and Microbiology, College of Science, King Saud University, Riyadh - 11451, Saudi Arabia. \\ ashebl@ksu.edu.sa; 2. Department of Chemistry of Natural and Microbial Products, Pharmaceutical Industries Research division, \\ National Research Center, El-Buhouth St., Dokki, Cairo 12311, Egypt. 3. Sudan Academy of Sciences, Council of Biological Sciences, \\ New technology and Environments, Khartoum, Sudan. 4. National Centre for Research, Khartoum, Sudan
}

\begin{abstract}
Alkaline proteases are hydrolytic enzymes that cleave peptide bonds in proteins and peptides in alkaline conditions, which occupy a pivotal importance with respect to their industrial applications. This study aimed to isolate new alkaline protease producing alkaliphilic bacteria from Egyptian soda lakes and optimize the fermentation process to enhance the enzyme production. The extensive screening process of the samples collected from Egyptian soda lakes resulted in isolation of a potent alkaline protease producing alkaliphilic strain AK-R. The isolate was identified as Bacillus agaradhaerens strain AK-R based on 16S rRNA gene analysis (99\%). Wheat bran and gelatin supported maximum alkaline protease production as carbon and nitrogen sources, respectively. Strain AK-R is halo-tolerant thermotolerant alkaliphilic bacterium in nature, as it can grow over a wide range of $\mathrm{NaCl}$ concentrations (up to $25 \%$ ) and up to 55 ${ }^{\circ} \mathrm{C}$, with maximal growth and enzyme production at $2.5-5 \%$, and $\mathrm{pH} 11$ at $35^{\circ} \mathrm{C}$. Among the tested cations, only $\mathrm{Mg}^{2+}$ and $\mathrm{Ca}^{2+}$ ions significantly enhanced the enzyme production by about 1.2 , and 1.3 fold compared to control, respectively. Alkaline protease secretion was coherent with the growth pattern, reaching maximal yield after about $32 \mathrm{~h}$ (mid stationary phase). In conclusion a new halo-tolerant thermo-tolerant alkaliphilic alkaline protease producing Bacillus agaradhaerens strain AK-R was isolated from Egyptian soda lakes. Optimization of the nutritional and cultivation conditions resulted in increase of enzyme yield by 20 fold. Strain AK-R and its extracellular alkaline protease with salt, $\mathrm{pH}$ and temperature, tolerance signify their potential application in laundry and pharmaceuticals industries.
\end{abstract}

KEYWORDS: Bacillus agaradhaerens. Soda lakes. Alkaline protease. Enzyme production. 16S rDNA. Fermentation

\section{INTRODUCTION}

Proteases are hydrolytic enzymes that cleave peptide bonds in proteins and peptides that occupy a pivotal importance with respect to their commercial and industrial applications (JOSHI et al., 2013). Within the enzyme market, proteases alone contribute approximately $60 \%$ of the total sales in the world; and microbial proteases constitute approximately $40 \%$ of the total worldwide production of enzymes (JAIN et al., 2012; JOSHI et al., 2013). Alkaline proteases, characterized by high activity and stability in high alkaline range, have various industrial applications including leather, pharmaceuticals, foods, diagnostic reagents, soy processing, peptide synthesis, re-cycling of X-ray film for silver extraction, and bioconversion of chitinous materials (SHAH et al., 2010; JELLOULI et al., 2011; JOSHI et al., 2012). However, the main application of alkaline proteases is in detergent industry, accounting for approximately $30 \%$ of the total world enzyme production, which is due to the alkaline $\mathrm{pH}$ of laundry detergents ingredients (HADDAR et al., 2009a). Alkaline proteases are used in detergents formulations, with other hydrolytic enzymes, as cleaning additives to facilitate the breakdown and release of proteins (JAIN et al., 2012). The increased commercial demand for highly active alkaline proteases with high specificity and stability continues to stimulate the search for new enzymes (VIJAYARAGHAVAN; VINCENT, 2012). As the origin of the alkaline protease is the key factor in determining its activity and properties, scientists are searching nature for better performing alkaline proteases. When searching nature for novel alkaline protease, samples from unexplored environments should be used; and one of such environments is extreme environment in which extremphilic microorganisms are enriched, i.e. halophilies, alkalophiles, thermophiles and others (HORIKOSHI et al., 2011). 
Alkaliphilic bacteria are group of microorganisms that grow better in alkaline environments, making them candidate strains for exploration of novel alkaline proteases for various biotechnological potential (JAYAKUMAR et al., 2012; GOHEL; SINGH, 2015). Soda lakes are one of the main natural habitats of alkaliphilic bacteria, representing the major types of naturally occurring highly alkaline environments with $\mathrm{pH}>11$ (HORIKOSHI, 1999). One of those environmental niches, which have not been studied in details, is hyper saline soda lakes located in Wadi El-Natrun valley (Egypt) (HORIKOSHI, 1999). However, the low productivity of enzymes and metabolites from extremophiles represent one of the major bottlenecks in their industrial applications, thus it is very important to optimize production medium and cultivation conditions in order to obtain high and commercial yields of alkaline protease (PATEL et al., 2005; PATEL et al., 2006). The present study focused on isolation of new alkaline producing alkaliphilic bacteria from Wadi El-Natrun soda lakes and optimization of the fermentation process in order to enhance the enzyme production.

\section{MATERIAL AND METHODS}

\section{Collection of Soil and Water Samples}

Water and sediment samples were collected from different hyper saline soda lakes located Wadi El-Natrun valley. This valley is an elongated depression approximately $90 \mathrm{~km}$ northwest of Cairo (Egypt) that extends in a northwest by southeast direction between latitudes $30^{\circ} 15^{\prime}$ north and longitude $30^{\circ} 30^{\prime}$ east. The bottom of Wadi ElNatrun valley is $23 \mathrm{~m}$ and $38 \mathrm{~m}$ below sea level and water level of Rosetta branch of the Nile, respectively, with average length and width of 60 $\mathrm{km}$ and $10 \mathrm{~km}$, respectively (TAHER, 1999). The collected samples were kept at $4{ }^{\circ} \mathrm{C}$, and transferred within few days to the laboratory at King Saud University (Riyadh, Saudi Arabia).

\section{Isolation of alkaline protease producing alkalipilic bacteria}

Alkaline protease producing alkalipilic bacteria were isolated from the collected samples using Horikoshi-I alkaline medium with some modification (HORIKOSHI, 1999). The modified Horikoshi-I alkaline medium ( $\mathrm{pH} 10.5)$ contained: glucose $(10 \mathrm{~g} / \mathrm{L})$, yeast extract $(5 \mathrm{~g} / \mathrm{L})$, peptone $(5$ $\mathrm{g} / \mathrm{L}), \mathrm{K}_{2} \mathrm{HPO}_{4}(1 \mathrm{~g} / \mathrm{L}), \mathrm{Mg}_{2} \mathrm{SO}_{4} .7 \mathrm{H}_{2} \mathrm{O}(0.2 \mathrm{~g} / \mathrm{L})$, $\mathrm{NaCl}(50 \mathrm{~g} / \mathrm{L}), \mathrm{Na}_{2} \mathrm{CO}_{3}(10 \mathrm{~g} / \mathrm{L})$, agar $(15 \mathrm{~g} / \mathrm{L})$, in addition to $10 \%(\mathrm{w} / \mathrm{v})$ skim milk as an indicator of alkaline protease production (SUNDARARAJAN et al., 2011). Sediment samples were suspended and serially diluted in glycine- $\mathrm{NaOH}$ buffer $(50 \mathrm{mM}, \mathrm{pH}$ 10). Aliquots (0.2-0.5 mL) of different dilutions were spread on the alkaline agar medium and incubated for several days at $30{ }^{\circ} \mathrm{C}, 40{ }^{\circ} \mathrm{C}, 50{ }^{\circ} \mathrm{C}$, and $60{ }^{\circ} \mathrm{C}$. Formation of clearing zone around the colonies resulted from the production of alkaline protease, and subsequent casein hydrolysis, was considered as an initial indication of protease activity (SUNDARARAJAN et al., 2011; VIJAYARAGHAVAN; VINCENT, 2012). The alkaline protease producing alkaliphilic isolates were sub cultured several times in fresh agar plates until single homogeneous colonies were obtained; and glycerol stocks of each strain were prepared and stored at $-80{ }^{\circ} \mathrm{C}$.

\section{Bacterial identification}

The alkaline protease producing bacterium was identified through sequencing and analysis of $16 \mathrm{~S}$ rRNA gene as previously reported (LANE, 1991). Total bacterial DNA was extracted from overnight culture using DNeasy Blood\& Tissue Kits (Qiagen) according to the manufacturer's instructions. Universal eubacterial-specific forward primer: 16F27 (5'-AGA GTT TGA TCC TGG CTC AG-3'), and reverse primer: 16R1525 (5'-AAG GAG GTG ATC CAG CCG CA-3') were used to amplify $16 \mathrm{~S}$ rDNA gene (LANE, 1991). The PCR reaction contained $(50 \mu \mathrm{L}): 18 \mu \mathrm{l}$ nuclease-free water, $25 \mu \mathrm{L}$ GoTaq® Green Master Mix (2×) (Promega), $1 \mu \mathrm{L}$ 16F27 $(10 \mu \mathrm{M}), 1 \mu \mathrm{L}$ 16R1525, and $5 \mu \mathrm{L}$ DNA template (200 $\mathrm{ng})$. The PCR reaction was run for 35 cycles under the following thermal profile in a DNA thermal cycler: Initial denaturation at $95{ }^{\circ} \mathrm{C}$ for $5 \mathrm{~min}$, denaturation at $95{ }^{\circ} \mathrm{C}$ for $1 \mathrm{~min}$, primers annealing at $52{ }^{\circ} \mathrm{C}$ for $1 \mathrm{~min}$, and extension at $72{ }^{\circ} \mathrm{C}$ for $1.5 \mathrm{~min}$. The final cycle included extension for $10 \mathrm{~min}$ at $72{ }^{\circ} \mathrm{C}$ to ensure full extension of the products. PCR product was run in $1.5 \%$ agarose gel electrophoresis and purified using a QIAquick gel extraction kit (Qiagen,) according to the manufacturer's instructions. The purified 16SrDNA amplicon was sequenced using an automated sequencer (Macrogen, Korea). The obtained sequence was aligned with the reference 16S-rDNA sequences available in National Centre for Biotechnology information (NCBI) homepage using the BLAST algorithm.

\section{Production of alkaline protease}

The alkaline medium used for bacterial isolation, without skim milk and agar, was used for alkaline protease production by the selected isolates. A loopful of the isolates culture from agar plates 
was inoculated into $50 \mathrm{~mL}$-glass tube containing 5 $\mathrm{ml}$ of the liquid production medium, and incubated overnight at $40{ }^{\circ} \mathrm{C}$ and $150 \mathrm{rpm}$. This culture was then inoculated into $250 \mathrm{~mL}$ capacity Erlenmeyer flask containing $50 \mathrm{~mL}$ of the same medium and incubated at $40{ }^{\circ} \mathrm{C}$ for about $24 \mathrm{~h}$. After the incubation period the culture was centrifuged at $10000 \mathrm{rpm}$ for $15 \mathrm{~min}$ at $4{ }^{\circ} \mathrm{C}$ to remove the cells and any insoluble materials. The cell-free supernatant was used to measure the alkaline protease activity as described below.

\section{Assay of alkaline protease}

Proteolytic activity was assayed by a modified method of Kunitz (KUNITZ, 1947). A 0.5$\mathrm{mL}$ of suitably diluted culture supernatant was mixed with $0.5 \mathrm{~mL}$ of $50 \mathrm{mM}$ glycine-NaOH buffer $(\mathrm{pH} 10)$ containing $1 \%(\mathrm{w} / \mathrm{v})$ casein and $10 \mathrm{mM}$ $\mathrm{CaCl}_{2}$; and incubated at $50{ }^{\circ} \mathrm{C}$ for $20 \mathrm{~min}$. Then, the reaction was terminated by addition of $0.5 \mathrm{~mL}$ of trichloroacetic acid $(20 \%, \mathrm{w} / \mathrm{v})$, and the mixture was allowed to stand at room temperature for $15 \mathrm{~min}$ before centrifugation at $10000 \mathrm{~g}$ for $15 \mathrm{~min}$ to remove the precipitate. The acid-soluble materials were estimated using Lowry method (LOWRY et al., 1951). A standard curve was generated using solutions of $0-100 \mu \mathrm{g} / \mathrm{mL}$ tyrosine. One unit of protease activity was defined as the amount of enzyme required to liberate $1 \mu \mathrm{g}$ of tyrosine per minute under the experimental conditions. All enzyme assay experiments were carried out in triplicate and the mean values were recorded.

\section{Optimization of alkaline protease production Effect of carbon source}

The influence of different carbon sources on the bacterial growth and alkaline protease production by the selected isolate were investigated by replacement of glucose in the production medium with other carbon sources $(1 \%, w / v)$ including: galactose, fructose, xylose, glucose, lactose, sucrose, starch, and wheat bran. Carbon sources were autoclaved separately and added to the medium on an equal carbon basis. In addition, the effects of different concentrations of the best carbon source, supporting maximal enzyme production, in the range of 0 to $2.5 \%$ were also investigated. The growth and enzyme activity were determined after $24 \mathrm{~h}$ of incubation at $40{ }^{\circ} \mathrm{C}$, in shaking incubator (150 rpm).

\section{Effect of nitrogen source}

Effect of different nitrogen sources on the bacterial growth and enzyme production by the alkaline protease producing isolate was investigated by substituting peptone and yeast extract in the production medium (Horikoshi-1) with different sources of organic and inorganic nitrogen sources at concentration of $0.5 \%(\mathrm{w} / \mathrm{v})$. Organic nitrogen sources included peptone, yeast extract, trypton, alkali soluble casein, insoluble casein, skim milk, gelatin, and beef extract; while inorganic nitrogen sources included ammonium nitrate, ammonium sulphate, sodium nitrate, and urea. Furthermore, the effects of different concentrations (0-2\%) of nitrogen source that support maximum enzyme yield were investigated. Bacterial growth and enzyme activity were measured after $24 \mathrm{~h}$ incubation at 40 ${ }^{\circ} \mathrm{C}$ in orbital shaking incubator (150 rpm).

\section{Effect of salinity and cations}

In addition to carbon and nitrogen source testing, the effects of $\mathrm{NaCl}$ concentration ranged from 0 to $25 \%$, and various metal ions, including $\mathrm{Mg}^{2+}, \mathrm{Mn}^{+2}, \mathrm{Zn}^{2+}, \mathrm{Ca}^{2+}, \mathrm{Cu}^{2+}, \mathrm{Co}^{2+}, \mathrm{Fe}^{2+}$, and $\mathrm{Ba}^{2+}$ at concentrations of $1 \mathrm{mM}, 5 \mathrm{mM}$, and $10 \mathrm{mM}$, on the bacterial growth and alkaline protease production was investigated, keeping the other parameters constant. The growth and enzyme activity were measured after $24 \mathrm{~h}$ incubation at $40{ }^{\circ} \mathrm{C}$ in orbital shaking incubator. All experiments and enzyme assays were carried out in triplicate and the mean values were reported.

\section{Effect of temperature, $\mathrm{pH}$, and aeration}

Influence of incubation temperature on the cells growth and enzyme production by the selected strain was investigated by varying the growth temperature in the range of 30 to $55^{\circ} \mathrm{C}$, keeping the other parameters constant. Similarly, in order to investigate the influence of initial $\mathrm{pH}$ of the production medium on growth and alkaline protease production, the isolate was grown in medium with different initial $\mathrm{pH}$ values ranged from 5.0 to 12.0 at the optimum growth temperature. The bacterial growth and enzyme activity were measured as described above after $24 \mathrm{~h}$ incubation period. Furthermore, influence of the aeration level during fermentation on growth and protease production was investigated by incubating the culture in shaking incubators with different rpm values ranged from zero (static) to $250 \mathrm{rpm}$.

\section{Bacterial growth versus alkaline proteases production}

A loopful of the isolate culture from agar plate was inoculated into $50 \mathrm{~mL}$-glass tube containing $5 \mathrm{~mL}$ of the liquid medium, and incubated overnight at $200 \mathrm{rpm}$ and $35{ }^{\circ} \mathrm{C}$. This culture was then inoculated into $500 \mathrm{~mL}$ capacity 
Erlenmeyer flask containing $250 \mathrm{~mL}$ of the same medium and incubated at $35^{\circ} \mathrm{C}$ for $48 \mathrm{~h}$. Samples (2 $\mathrm{mL}$ ) were withdrawn at $2 \mathrm{~h}$ interval up to $48 \mathrm{~h}$ for measurement of cells growth and alkaline protease activity. The samples were centrifuged at $10000 \mathrm{rpm}$ at $4{ }^{\circ} \mathrm{C}$; and the pellets obtained were washed twice using Tris buffer $(50 \mathrm{mM}, \mathrm{pH} 8)$ and resuspended in $1 \mathrm{~mL}$ of the same buffer. Absorbance was measured at $600 \mathrm{~nm}$ against $50 \mathrm{mM}$ Tris Buffer $(\mathrm{pH} \mathrm{7})$ as blank, was reported as growth of the organism. Alkaline protease activity was measured in the cellfree supernatant as described above. Triplicate of each time period was taken to calculate growth and enzyme activity and the mean values were reported.

\section{Statistical analysis}

All the experiments and assays were performed in triplicate; and the standard deviation for each experiment was calculated using SPSS 14.0 and are indicated in the figures as error bars (JAYAKUMAR et al., 2012).

\section{RESULTS AND DISCUSSION}

\section{Isolation of the microorganism}

Isolation of alkaline protease producing alkaliphilic bacteria was carried out using rich alkaline agar medium containing skim milk. Formation of clear zone around the colonies was considered as indication of alkaline protease production. After the incubation period, several morphologically distinct colonies showed zone of hydrolysis indicating production of extracellular alkaline protease and subsequent casein hydrolysis (Figure 1). Individual positive isolates were purified through repeated streaking on fresh agar plates. It has been established that there is not necessarily good correlation between zones of clearing around colonies on milk-agar plates and levels of proteinase activity (COOLBEAR et al., 1991). Therefore, all the positive isolates were cultivated in the alkaline production medium and the proteolytic activity was measured. The results indicated that strain AK-R showed high alkaline protease activity $(36.3 \mathrm{U} / \mathrm{mL})$ and was selected for further investigation.
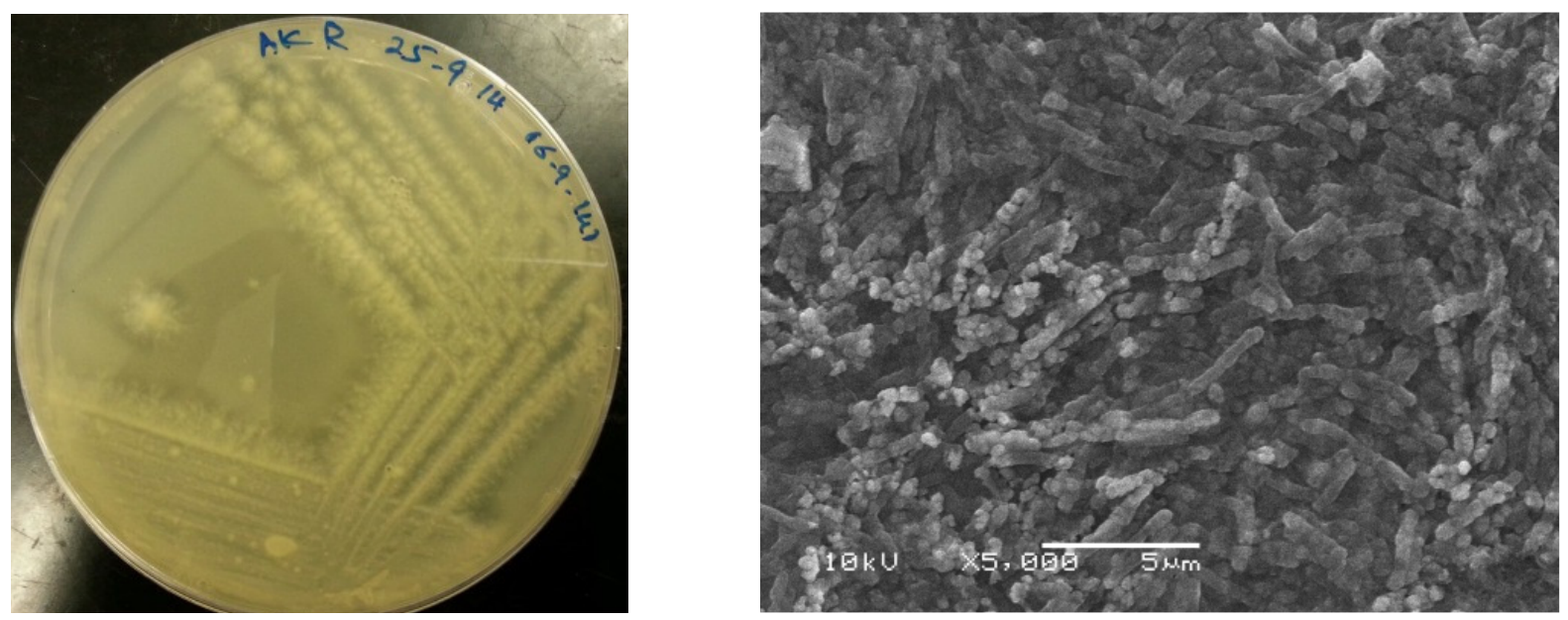

Figure 1. A; Isolation of alkaline protease alkaliphilic bacteria using modified Horikoshi-I agar plate containing $10 \%(\mathrm{w} / \mathrm{v})$ skim milk. The clear zone indicated casein hydrolysis due to alkaline protease production. B: Scanning Electron Microscope (SEM) image of strain AK-R.

The alkaline protease producing strain AK$\mathrm{R}$, grown in the alkaline agar medium showed white rhizoid colonies with filamentous margin which characterized by its adhesion to agar (Figure 1). Culture grown in alkaline liquid medium for $24 \mathrm{~h}$ showed motile short rod-shaped cells with length of about $2.5 \mu \mathrm{m}$ and $0.3 \mu \mathrm{m}$ in diameter. Cells existed as single, paired or short chain. Strain AK-R was able to grow in the presence of $\mathrm{NaCl}$ up to $25 \%$ (w/v), showing growth at $30{ }^{\circ} \mathrm{C}$ to $55^{\circ} \mathrm{C}$ but no growth was observed at $60{ }^{\circ} \mathrm{C}$ after $48 \mathrm{~h}$ incubation period. It could grow at $\mathrm{pH}$ value from 8 to 12 , with poor growth detected at $\mathrm{pH} 7$ after $48 \mathrm{~h}$ incubation. In order to determine the phylogenetic position of strain AK-R, 16S rDNA sequence analysis was performed. A total of 1462 nucleotides of strain AK-R 16S rRNA gene were determined. It showed highest similarity with Bacillus agaradhaerens DSM 8721 (99\%) and was designed as Bacillus agaradhaerens strain AK-R. Figure 2 shows the phylogenetic tree of strain AK-R and its closest bacteria based on 16S rRNA gene sequences. The sequence of strain AK-R 16S rRNA gene was deposited in GenBank with accession number 
KP316022. Bacillus agaradhearens was firstly described as a new alkaliphilic Bacillus species by Nielsen et al (NIELSEN et al., 1995). A variety of polysaccharides-degrading enzymes including cellulase, xylanase, xyloglucanase, mannanase, and pectate lyase from $B$. agaradhaerens have been studied for other applications (SCHULEIN, 1999; $\mathrm{XU}, 2000$ ). In addition, new isolate identified as Bacillus agaradhaerens strain nandiniphanse5 has proved to produce alkaline protease but not yet investigated (PHANSE et al., 2013).

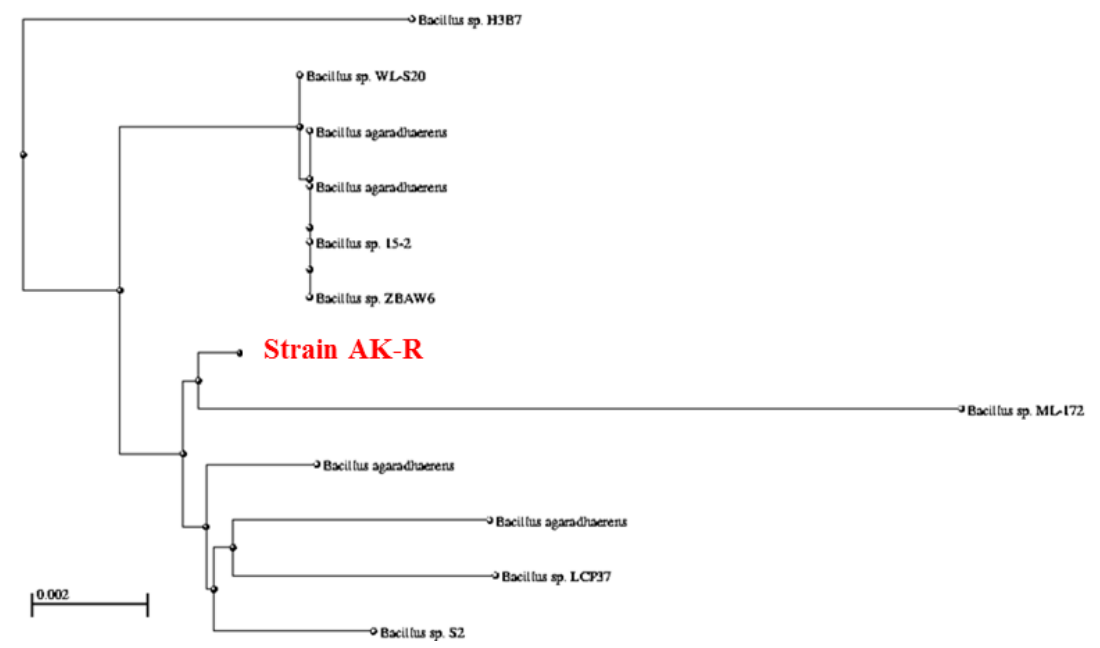

Figure 2. Neighbor-joining phylogenetic tree of the isolated strain AK-R and its closest bacteria based on $16 \mathrm{~S}$ rRNA gene sequences.

\section{Production optimization of alkaline proteases}

It is clear from the literature that production of extracellular protease is highly influenced by media components including carbon and nitrogen source, presence of simple sugars, and salts. In addition to the fermentation conditions including culture aeration level, media $\mathrm{pH}$, growth temperature, and incubation time (GOUDA, 2006; MEENA et al., 2013). Therefore it is essential to optimize the fermentation process in order to obtain high and commercial yields of alkaline protease by the new isolate of Bacillus agaradhaerens strain AK-R.

\section{Effect of carbon source}

Influence of different carbon sources, including mono-, di- and polysaccharides, in addition to wheat bran on strain AK-R growth and alkaline protease production was investigated. Despite all tested carbon sources supported the cells growth; various carbon sources were found to have different impact on the production of protease by strain AK-R (Figure 3). The results revealed that wheat bran was the best carbon source that enhanced the alkaline protease production by about 3.8 fold compared to the control as carbon source. This was followed by fructose, starch, xylose, and lactose, respectively. However, glucose, galactose, maltose, and sucrose caused severe reduction of protease production by strain AK-R, with production yield of $26.6 \%, 24.4 \%, 15.5 \%$, and $13.3 \%$ in comparison to maximal yield obtained using wheat bran, respectively. The production of alkaline protease was further monitored at various concentration of wheat bran, as the best carbon source.

As shown in Figure 4 both cells growth and alkaline protease production were increased by increasing the wheat bran concentration, reaching maximal bacterial growth and enzyme production at $1.5 \%$. This result is in accordance with that reported for alkaliphilic Bacillus sp. MIG (GOUDA, 2006), Pseudomonas aeruginosa (MEENA et al., 2013), and Bacillus cereus strain CA15 (MEENA et al., 2013), where wheat bran supported maximum alkaline protease production. The use of wheat bran in the production medium is very important, because it is one of the cheap and readily available carbon sources. The estimated cost of wheat bran was found to be $0.002 \$$ for one liter production medium (GOUDA, 2006). On the other hand, other carbon sources were reported for maximal protease production based on the source organism (JOSHI et al., 2008; SHIVANAND; JAYARAMAN, 2009; JAYAKUMAR et al., 2012). Less production of alkaline protease by $B$. agaradhaerens strain AK-R in the presence of simple sugar like glucose, galactose, sucrose, and maltose is mostly due to catabolite repression of protein biosynthesis (KANEKAR et al., 2002; DENG et al., 2010). 


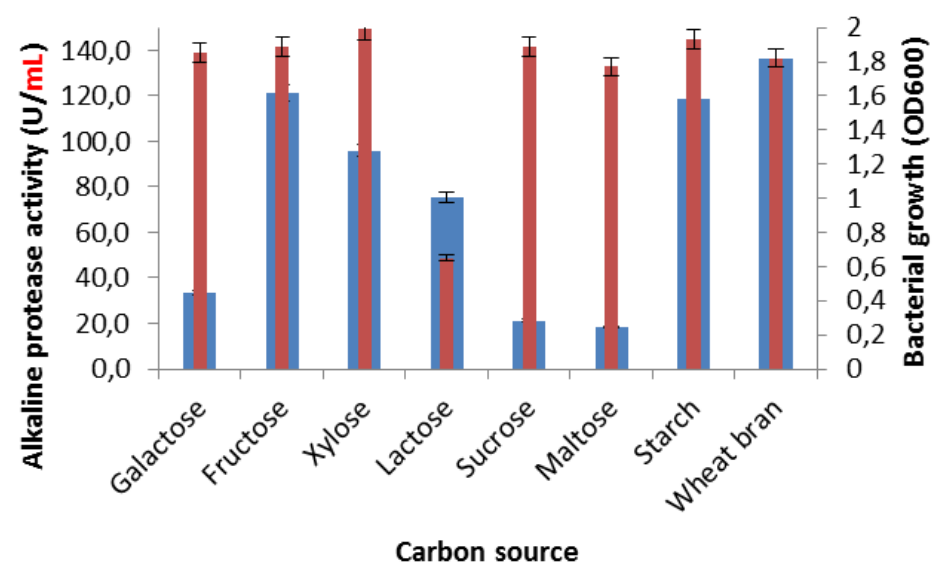

n Alkaline protease activity (U/ml) \# Bacterial growth (OD $600 \mathrm{~nm})$

Figure 3. Influence of various carbon sources on strain AK-R growth and alkaline proteases production by strain AK-R. Bacterial growth and alkaline protease activity were determined after incubation for $24 \mathrm{~h}$ at $40{ }^{\circ} \mathrm{C}$ under shaking conditions $(150 \mathrm{rpm})$. Standard deviations $(\mathrm{n}=3)$ are reported as error bars.

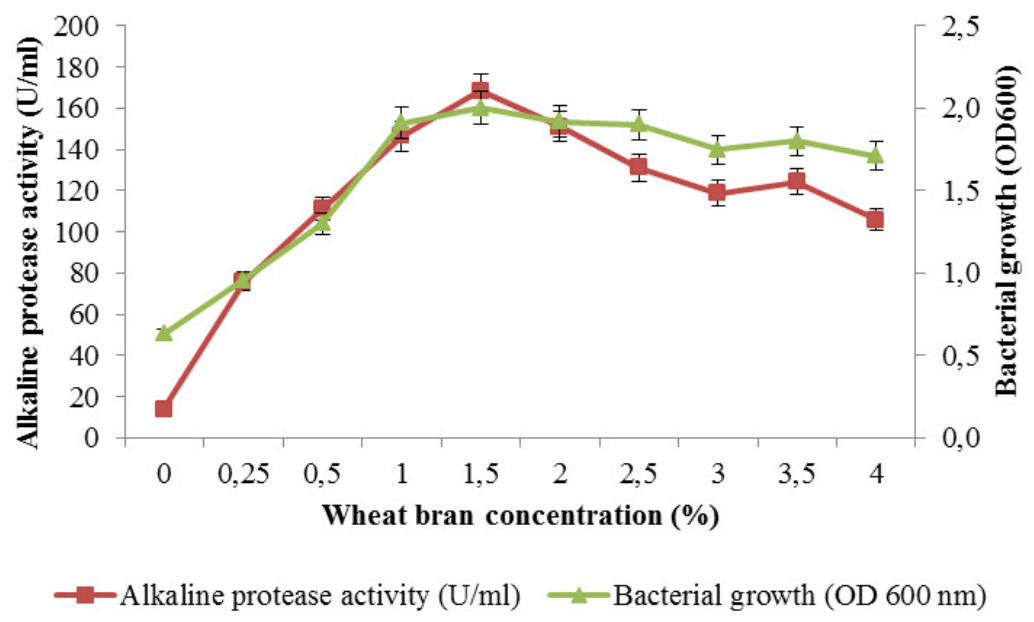

Figure 4. Effect of wheat bran concentration on growth and alkaline proteases production by strain AK-R. Cells growth and alkaline protease activity were determined after incubation for $24 \mathrm{~h}$ at $40{ }^{\circ} \mathrm{C}$ under shaking conditions (150 rpm). Error bars represent the standard deviations $(\mathrm{n}=3)$.

\section{Effect of nitrogen source}

The effect of different nitrogen sources on B. agaradhaerens strain AK-R growth and alkaline protease production was evaluated using wheat bran as a carbon source. The results shown in Figure 5 indicated that several organic nitrogen sources supported both bacterial growth and alkaline protease production, showing maximum enzyme production in medium containing gelatin, followed by skim milk, and alkali soluble casein, that the enzyme yield increased by about 1.6, 1.3, and 1.2 compared to control, respectively. Regarding inorganic nitrogen source, while urea showed less growth and protease production than the control, ammonium sulphate and ammonium nitrate were unfavorable for either cells growth or alkaline protease production with enzyme yield of about $9.0 \%$ and $10.9 \%$ of the maximum production, respectively. 


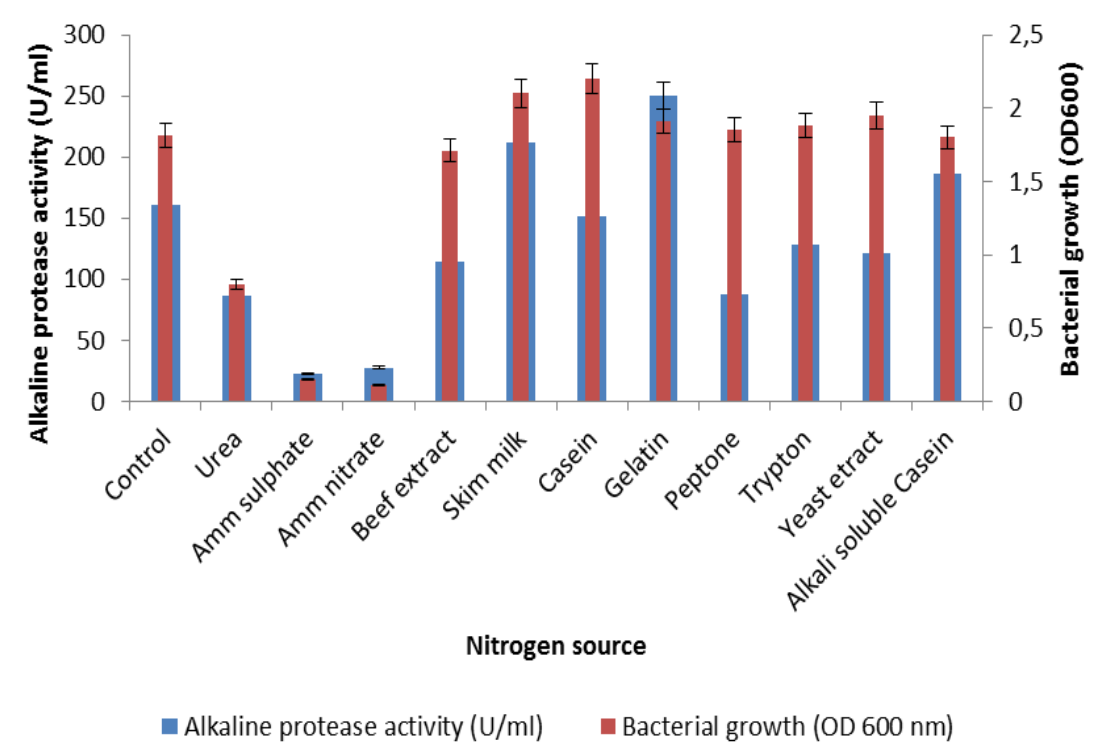

Figure 5. Influence of nitrogen sources on bacterial growth and alkaline protease production by strain AK-R, using wheat bran as a carbon source. Error bars represent the standard deviations $(n=3)$.

The production of alkaline protease by strain AK-R was further monitored at various concentration of gelatin. Both bacterial growth and enzyme production was increased by increasing the gelatin concentration, showing maximum enzyme yield at concentrations of $1 \%$ (Figure 6). Further increase of gelatin led to slight decrease of the enzyme production, with no effect on the bacterial growth. This result was in agreement with that reported for other Bacillus sp where alkaline protease production was maximal using gelatin and significantly reduced using inorganic nitrogen sources (SHAH et al., 2010; RAJA et al., 2012).
However, other organic nitrogen sources were found to support protease production in other microorganisms including yeast extract (DENG et al., 2010); beef extract (KUMAR et al., 2014), casamino acids (JAIN et al., 2012), skim milk (GOUDA, 2006), peptone (OSKOUIE et al., 2008), and others (SRIVIDYA; MALA, 2011). Slight decrease of alkaline protease production by strain AK-R at high gelatin concentration may due to repression role of excessive amino acid and ammonium ions in alkaline protease production (JOO et al., 2003; CHU, 2007).

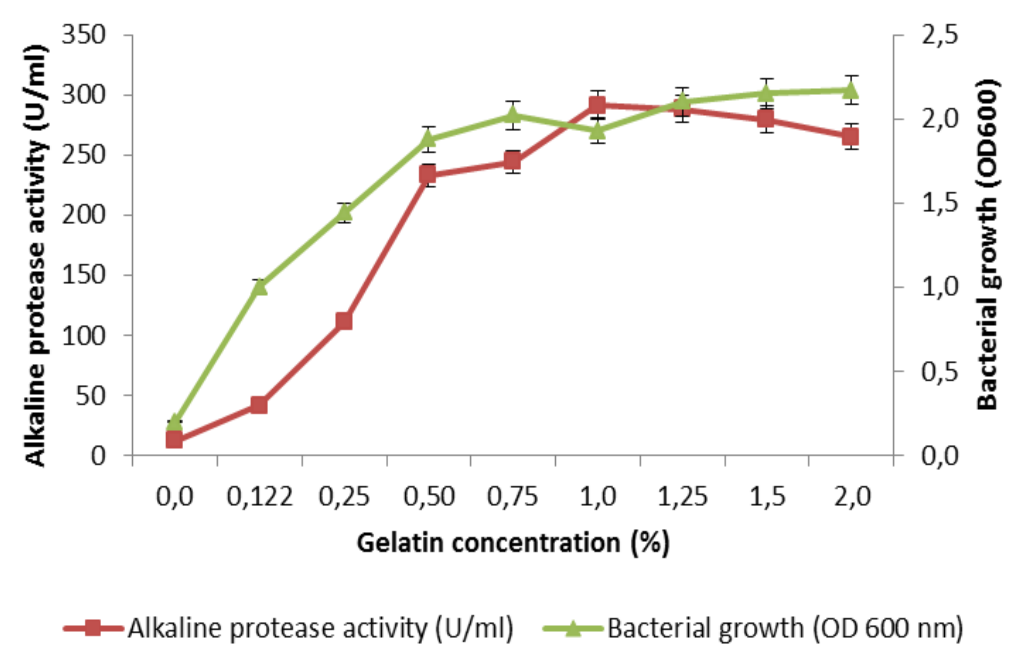

Figure 6. Influence of gelatin concentration on bacterial growth and production of alkaline proteases by strain AK-R. Bacterial growth and alkaline protease activity were determined after incubation for $24 \mathrm{~h}$ at $40{ }^{\circ} \mathrm{C}$ under shaking conditions (150 rpm). Standard deviation $(\mathrm{n}=3)$ are indicated as error bars. 


\section{Effect of salinity}

In order to investigate the effect of salinity on the cells growth and alkaline protease production by $B$. agaradhaerens strain AK-R, the production medium was supplemented with various concentration of $\mathrm{NaCl}$. The results revealed that strain AK-R can grow over a wide range of $\mathrm{NaCl}$ concentrations from 0 to $25 \%$, showing maximal growth and enzyme production at $\mathrm{NaCl}$ concentration of $2.5-5.0 \%$. While at $7.5 \% \mathrm{NaCl}$ there was slight decrease in the protease production to about $79 \%$ of the maximal yield, drastic decrease in enzyme production occurred at $10 \% \mathrm{NaCl}$ to about $20 \%$ of the maximal protease production (Figure 7). The ability of strain AK-R to grow over a wide range of $\mathrm{NaCl}$ concentrations (up to $25 \%$ ), with maximum cells growth at $2.5-5 \% \mathrm{NaCl}$, indicated the halo-tolerance nature of this organism (JAIN et al., 2012). Studies on the effect of salinity on growth of halotolerant bacteria have shown a change in the polar lipid composition of the cell membranes and an increased salt concentration creates change in the lipid resulting in decrease of growth rate causing reduced enzyme production (TANG, X. M. et al, 2004). Strain AK-R and its extracellular alkaline protease with salt tolerance signify their potential application in laundry industry (HADDAR et al., 2009b).

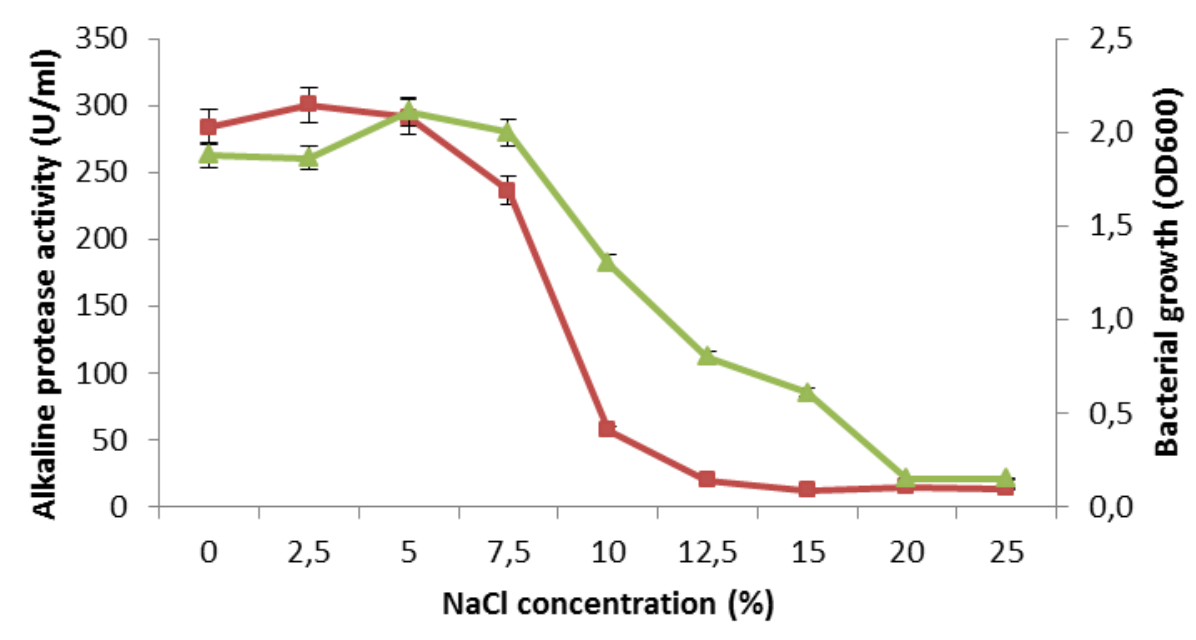

\section{$\simeq$ Alkaline protease activity $(\mathrm{U} / \mathrm{ml}) \multimap$ Bacterial growth $(\mathrm{OD} 600 \mathrm{~nm})$}

Figure 7. Influence of sodium chloride concentration on growth and production of alkaline proteases by strain AK-R. Bacterial growth and alkaline protease activity were determined after incubation for $24 \mathrm{~h}$ at $40{ }^{\circ} \mathrm{C}$ under shaking conditions $(150 \mathrm{rpm})$. Standard deviation $(\mathrm{n}=3)$ are indicated as error bars.

\section{Effect of various metals}

In order to investigate the influence of various metals on strain AK-R growth and alkaline protease yield, the production medium was supplemented with different concentrations of metals salts. Among the tested cations, only $\mathrm{Mg}^{2+}$ and $\mathrm{Ca}^{2+}$ ions significantly enhanced the enzyme production by about 1.2, and 1.3 fold compared to the control, respectively (Figure 8). On the other hand, while $\mathrm{Ba}^{2+}$ caused significant decrease in the protease production, $\mathrm{Fe}^{2+}, \mathrm{Mn}^{2+}, \mathrm{Co}^{2+}, \mathrm{Zn}^{2+}$ and ions led to drastic inhibition of the enzyme production to less than $6 \%$ of the yield compared to the control. This result is in agreement with that reported for production of alkaline protease production by other Bacillus sp (NADEEM et al., 2007; UYAR et al., 2011) and alkaliphilic Haloalkaliphilic Bacterium S20-9 (JOSHI et al., 2008), where $\mathrm{Ca}^{2+}, \mathrm{Mg}^{2+}$ ions significantly enhanced the enzyme production. These cations probably protect the enzyme against thermal denaturation and therefore maintain the active conformation of the enzyme at high temperature (CHU, 2007). In addition; the inhibitory effect of other ions on alkaline protease is mostly attributed to metal catalyzed oxidation of amino acid residues essential to the enzyme activity (TANG et al., 2004). 


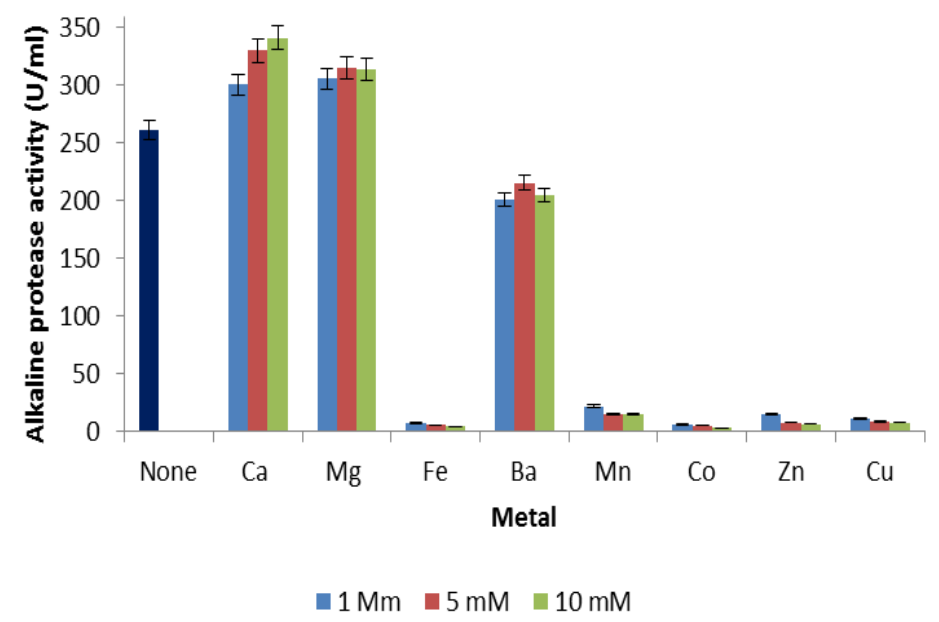

Figure 8. Influence of various cations on alkaline protease production by Bacillus agaradhaerens AK-R. The medium was supplemented with various metals at concentrations of $1 \mathrm{mM}, 5 \mathrm{mM}$ and $10 \mathrm{mM}$. Standard deviation $(n=3)$ are indicated as error bars.

\section{Effect of incubation temperature, media $\mathrm{pH}$, and} aeration level

The incubation temperature is an important factor affecting the bacterial growth and enzyme production (CHU, 2007; SRIVIDYA; MALA, 2011). The cells growth and alkaline protease production by strain $\mathrm{AK}-\mathrm{R}$ were studied at various growth temperatures ranged from $30{ }^{\circ} \mathrm{C}$ to $55^{\circ} \mathrm{C}$.
Maximum bacterial growth and enzyme production were seen at $35^{\circ} \mathrm{C}$ (Figure 9). At higher temperature enzyme production decreased to $65.2 \%$ and $36.7 \%$ of the maximum yield at growth temperatures of 40 ${ }^{\circ} \mathrm{C}$ and $45^{\circ} \mathrm{C}$, respectively. B. agaradhaerens strain AK-R can grow up to $55^{\circ} \mathrm{C}$ with no growth seen at $60{ }^{\circ} \mathrm{C}$, indicating that this organism is thermotolerant bacterium (SRIVIDYA; MALA, 2011).

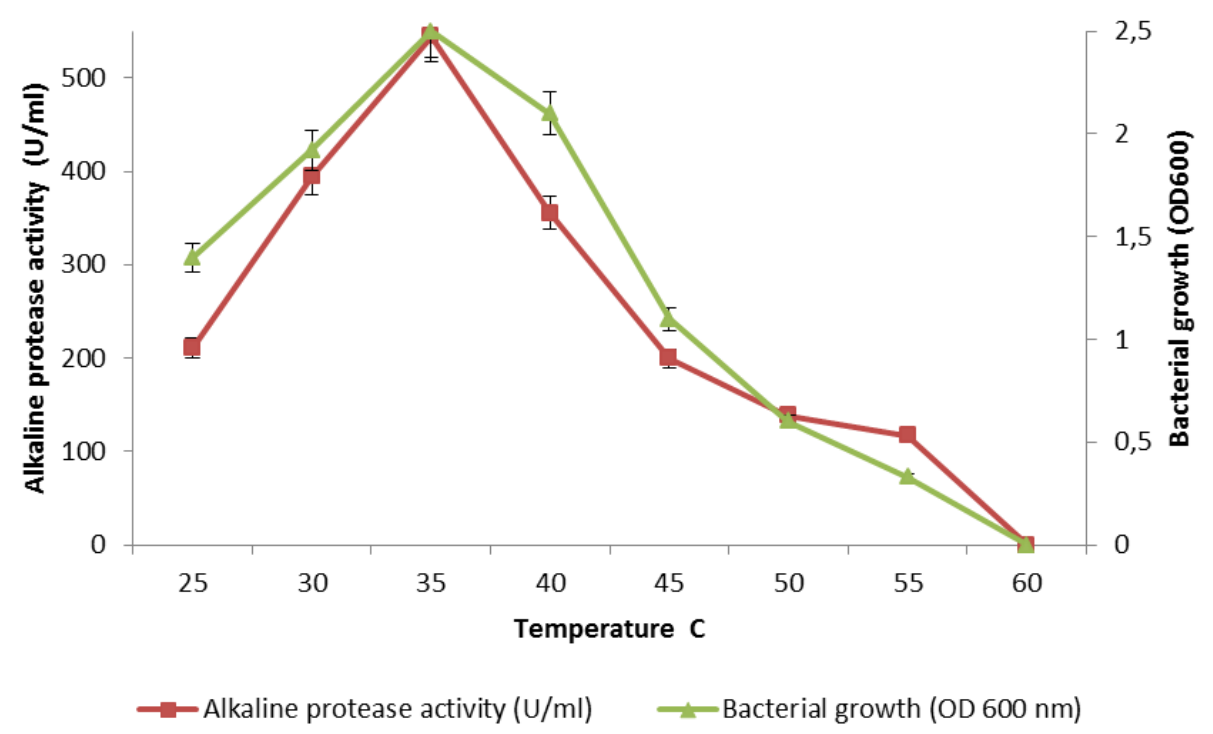

Figure 9. Influence of incubation temperature on bacterial growth and alkaline protease production by strain AK-R. Cells growth and alkaline protease activity were determined after incubation for $24 \mathrm{~h}$ at 40 ${ }^{\circ} \mathrm{C}$ under shaking conditions (150 rpm). Error bars represent the standard deviations ( $\left.\mathrm{n}=3\right)$.

The effects of initial medium $\mathrm{pH}$ values on the cells growth and protease production were investigated and the results are shown in Figure 10. B. agaradhaerens strain AK-R could grow and produce alkaline protease over a wide $\mathrm{pH}$ range from 7 to 12, with maximal growth and enzyme production observed at $\mathrm{pH} 11$. However, enzyme production was decreased to about $49.5 \%$ of the maximum yield at $\mathrm{pH} 12$. In addition, no growth was seen at $\mathrm{pH} 5$ or 6 . Requirement of alkaline $\mathrm{pH}$ for optimum growth and protease production obviously indicated the alkaliphilic nature of this 
bacterium and its enzyme. Alkaliphilic microorganisms are characterized by optimum

growth $\mathrm{pH}$ ranged from 9 to 11 (HORIKOSHI et al., 2011).

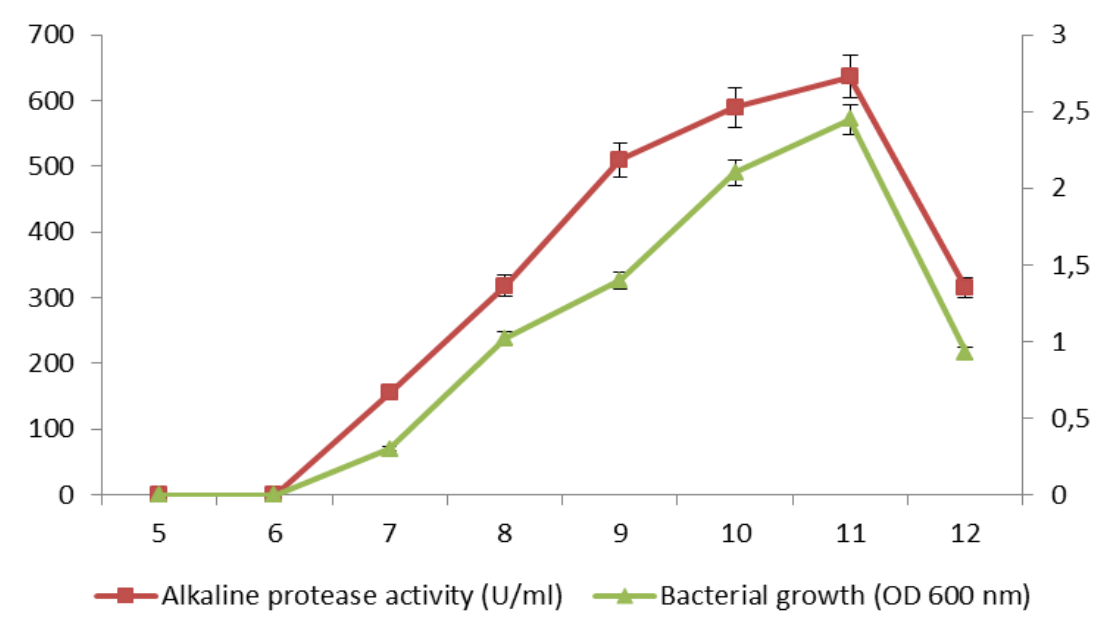

Figure 10. Influence of the initial $\mathrm{pH}$ of the culture medium on bacterial growth and alkaline protease production by strain AK-R. Error bars represent the standard deviations $(n=3)$.

Finally, the effect of culture aeration level on bacterial growth and protease production by strain AK-R was studied by incubating the cultures at various shaking speeds ranged from 0 to $250 \mathrm{rpm}$. The growth was significantly affected under static conditions and due to poor growth; protease production was reduced to about $16.7 \%$ of the maximal enzyme yield (Figure 11). Both bacterial growth and enzyme production increased with increasing aeration level up to $200 \mathrm{rpm}$. Sever reduction of cells growth and alkaline protease production under static condition indicated the aerobic nature of strain AK-R and the importance of high aeration level for alkaline protease production by this isolate. This result was relatively similar to that that reported for Halophilic Bacterium MBIC3303 (JOSHI et al., 2008) and Bacillus mojavensis (BEG et al., 2002; JOSHI et al., 2008), where the bacterial growth was completely reduced under static condition and increased significantly by increasing of the aeration level.

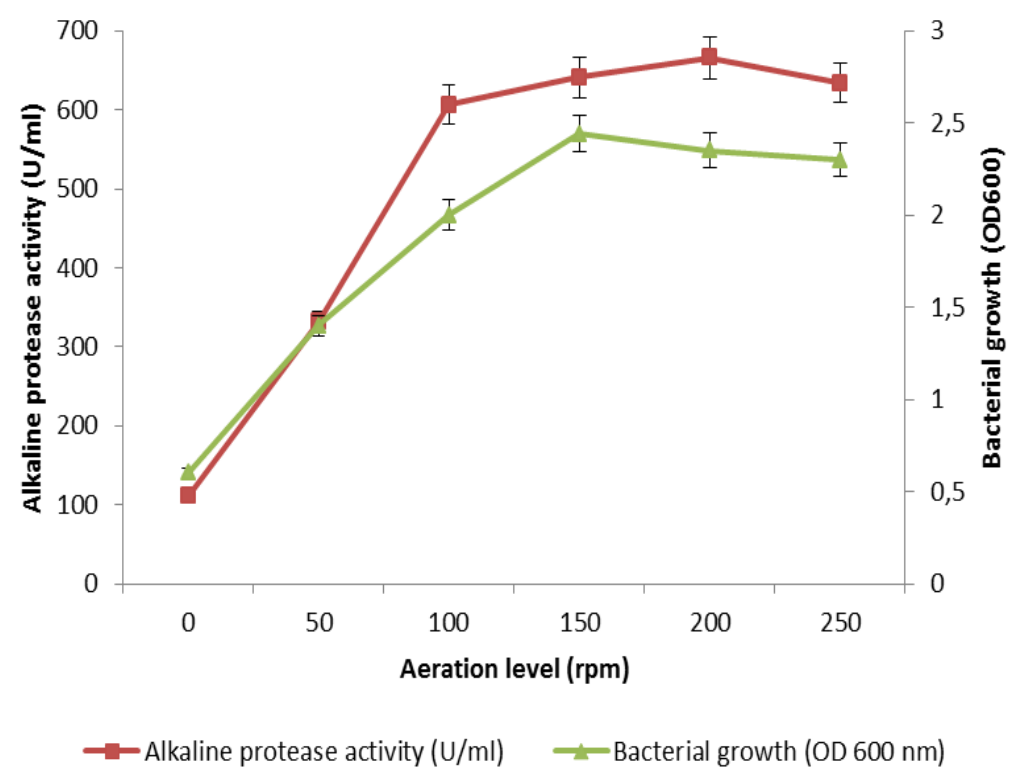

Figure 11. Influence of aeration level (shaking rpm) on cell growth and alkaline protease production by strain AK-R. Cells were propagated under the optimized medium with $\mathrm{pH} 11$ and incubated in shaking incubators with various rpm at $35^{\circ} \mathrm{C}$ for $24 \mathrm{~h}$. Standard deviations $(\mathrm{n}=3)$ are seen as error bars. 
Time course of bacterial growth versus and alkaline proteases production

B. agaradhaerens strain AK-R was grown under the optimized medium and culture conditions for $48 \mathrm{~h}$; and both cells growth and alkaline protease production were measured $2 \mathrm{~h}$ intervals. As shown in Figure 12 strain AK-R entered into the exponential phase after about $8 \mathrm{~h}$ and stationary phase started after about $28 \mathrm{~h}$. Production of extracellular alkaline protease was coherent with the cells growth, started shortly after the beginning of the exponential phase and reached maximum yield in the mid stationary phase with the highest activity detected after about $32 \mathrm{~h}(686.7 \mathrm{U} / \mathrm{mL})$. The enzyme production thereafter remained nearly constant at maximal level along with the stationary phase up to $42 \mathrm{~h}$. Production of the alkaline protease during the stationary phase indicated the significant role of extracellular proteases in metabolism and survival of this organism (JOSHI et al., 2008). This secretion pattern of alkaline protease is quite similar to that of haloalkaliphilic Bacillus sp. Po2 and alkalophilic Bacillus sp. B001 where maximal protease production was detected at the mid stationary phase (PATEL et al., 2005; RAJA; PRABHAHAR, 2012). However, protease section by Bacillus pumilus MCAS8 was found to be at late stationary phase (48 h) (JAYAKUMAR et al., 2012).

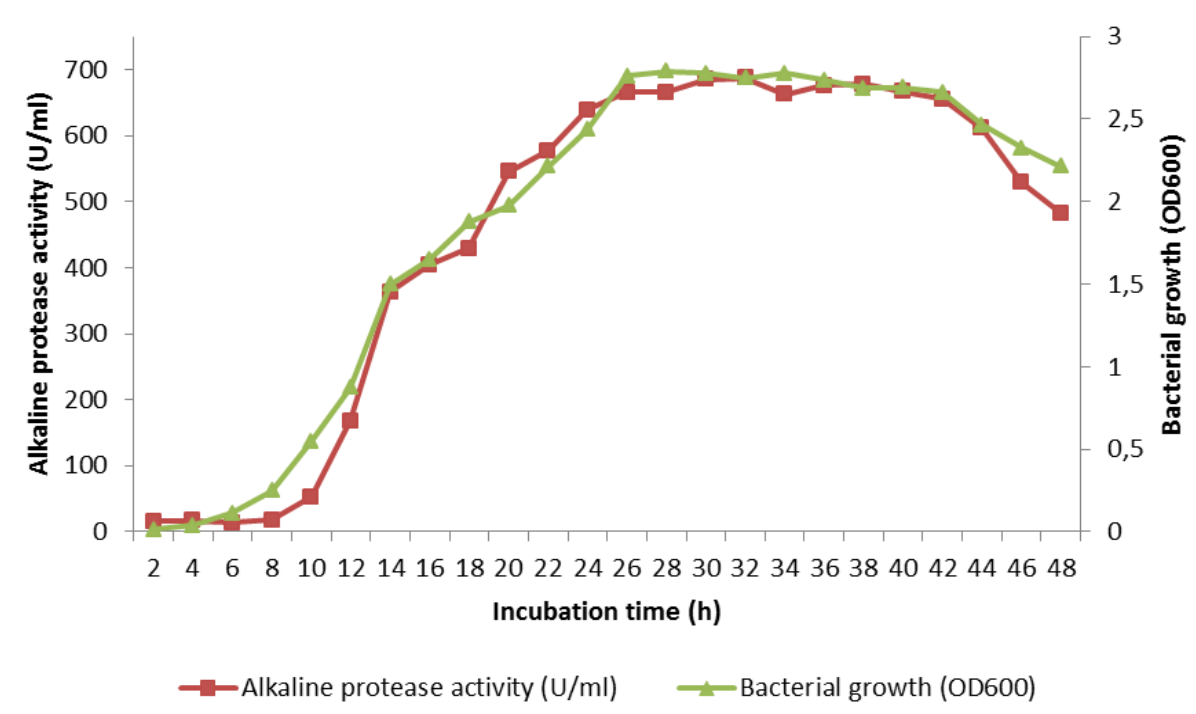

Figure 12. Time course of bacterial growth versus and alkaline proteases production by Bacillus agaradhaerens AK-R. Cells were grown in the optimized alkaline production medium and conditions, at $\mathrm{pH} 11$ for $48 \mathrm{~h}$ at $35^{\circ} \mathrm{C}$ and $200 \mathrm{rpm}$. Samples were withdrawn at $2 \mathrm{~h}$ interval for the determination of cell growth. Standard deviations $(n=3)$ were in range of 1.2 to $3.5 \%$

\section{CONCLUSIONS}

When searching nature for novel alkaline protease, samples from unexplored environments should be used; and one of such environments is hyper saline soda lakes in Wadi EL-Natrun valley.

The features of Wadi EL-Natrun valley created an ecosystem that considers as rich sources for isolation of alkaliphilic, haloalkalipilic and thermoalkaliphilic microorganisms.

A new potent alkaline protease producing alkaliphilic strain AK-R was isolated from the collected samples and identified as Bacillus agaradhaerens strain AK-R.

Extensive optimization of the nutritional and cultivation conditions of growth and alkaline protease production resulted in increase of enzyme yield by 20 fold, indicating significance of optimization of the fermentation parameters to obtain commercial yield of the enzyme.

$B$. agaradhaerens strain AK- $\mathrm{R}$ is halotolerant thermo-tolerant alkaliphilic bacterium with high alkaline protease production yield. Hence, this new isolate is a promising candidate for alkaline protease production for potential industrial applications. To best of our knowledge this is the first report about optimization of protease production from Bacillus agaradhaerens. Purification and characterization of alkaline protease from $B$. agaradhaerens strain AK-R are in progress to be published elsewhere.

\section{ACKNOWLEDGMENT}

This project was funded by the National Plan for Science, Technology and Innovation 
(MAARIFAH), King Abdulaziz City for Science and Technology, Kingdom of Saudi Arabia, Award Number (12-BIO2899-02).

RESUMO: Proteases alcalinas são enzimas hidrolíticas que quebram ligações peptídicas em proteínas e peptídeos em condições alcalinas, o que ocupa uma importância fundamental em relação às suas aplicações industriais. Este estudo teve como objetivo isolar novas proteases alcalinas e produzir bactérias alcalófilas a partir dos lagos salgados alcalinos egípcios e otimizar o processo de fermentação para aumentar a produção de enzimas. O extensivo processo de triagem das amostras coletadas dos lagos salgados alcalinos egípcios resultou no isolamento de uma protease alcalina potente produzindo uma estirpe alcalófila AK-R. O isolado foi identificado como sendo a estirpe AK-R de Bacillus agaradhaerens baseado na análise de genes 16S rRNA (99\%). O farelo de trigo e a gelatina suportaram a produção máxima de protease alcalina como fontes de carbono e nitrogênio, respectivamente. A estirpe AK-R é uma bactéria alcalófila halotolerante e termotolerante, pois pode crescer dentro de uma vasta gama de concentrações de $\mathrm{NaCl}($ até $25 \%)$ e até $55^{\circ} \mathrm{C}$, com crescimento e produção de enzimas máximos a $2.5-5 \%$ e pH 11 a $35^{\circ} \mathrm{C}$. Dentre os cátions testados, somente os íons $\mathrm{Mg} 2+$ e $\mathrm{Ca} 2+$ aumentaram significativamente a produção de enzimas em cerca de 1.2 e 1.3 em comparação ao controle, respectivamente. A secreção de protease alcalina foi coerente com o padrão de crescimento, atingindo o rendimento máximo após 32h (fase estacionária média). Pode-se concluir que uma nova estirpe AK-R de Bacillus agaradhaerens halotolerante, termotolerante e alcalófila produtora de protease alcalina foi isolada a partir dos lagos salgados alcalinos egípcios. A otimização das condições de nutrição e cultivo resultou num aumento da produção de enzima em 20 vezes. A estirpe AK-R e a sua protease alcalina extracelular com tolerância ao sal, pH e temperatura tornam significantes as suas potenciais aplicações nas indústrias farmacêutica e de lavanderia.

PALAVRAS-CHAVE: Bacillus agaradhaerens. Lagos salgados alcalinos. Protease alcalina. Produção de enzimas. 16S rDNA. Fermentação.

\section{REFERENCES}

BEG, Q. K.; SAXENA, R. K.; GUPTA, R. Derepression and subsequent induction of protease synthesis by Bacillus mojavensis under fed-batch operations. Process Biochemistry, v. 37, n. 10, p. 1103-1109, 2002. http://dx.doi.org/10.1016/S0032-9592(01)00320-X

CHANDRAN, S.; MADHAVAN, N. K, Ashok P. Microbial proteases. Microbial enzymes and biotransformations. Humana Press, 2005, chapter. 17, p. 165-179.

CHU, W. H. Optimization of extracellular alkaline protease production from species of Bacillus. Journal of Industrial Microbiology and Biotechnology, v. 34, p. 241-245, 2007. http://dx.doi.org/10.1007/s10295-006$0192-2$

COOLBEAR, T.; EAMAS, C. V.; CASE, Y.; DANIEL, R. M.; MORGEN, H. W. Screening of strains identified as extremely thermophilic bacilli for extracellular proteolytic activity and general properties of the proteinase from two of the strains. Journal of Applied Bacteriology, v. 71, n. 3, p. 252-264, 1991.

http://dx.doi.org/10.1111/j.1365-2672.1991.tb04456.x

DENG, A.; W. U, J.; ZHANG, Y.; ZHANG, G.; WENA, T. Purification and characterization of a surfactant stable high-alkaline protease from Bacillus sp. B001. Bioresource Technology, v. 101, n. 7, p. 100-106, 2010. http://dx.doi.org/10.1016/j.biortech.2010.03.130

GOHEL, S. D.; SINGH, S. P. Thermodynamics of a $\mathrm{Ca}^{2+}$-dependent highly thermostable alkalineprotease from a haloalkliphilic actinomycete. International Journal of Biological Macromolecules, v. 72, p. 421-29, 2015. http://dx.doi.org/10.1016/j.ijbiomac.2014.08.008

GOUDA, M. K. Optimization and purification of alkaline proteases produced by marine Bacillus sp. MIG newly isolated from eastern harbour of Alexandria. Polish Journal of Microbiology, v. 55, n. 2, p. 119-126, 2006. PMID: 17419289 
HADDAR, A.; AGREBI, R.; BOUGATEF, A.; HMIDET, N.; SELLAMI-KAMOUN, A.; NASRI, M. Two detergent stable alkaline serine-proteases from Bacillus mojavensis A21: Purification, characterization and potential application as a laundry detergent Additive. Bioresource Technology, v. 100, n. 13, p. 3366-3373, 2009. http://dx.doi.org/10.1016/j.biortech.2009a.01.061

HADDAR. A.; BOUGATEF, A.; AGREBI, R.; SELLAMI-KAMOUN, A.; NASRI, M. A novel surfactantstable alkaline serine-protease from a newly isolated Bacillus mojavensis A21. Purification and characterization. Process Biochemistry, v. 44, p. 29-35, 2009 b.

http://dx.doi.org/10.1016/j.procbio.2008.09.003

HORIKOSHI, K. Alkaliphiles: Some Applications of Their Products for Biotechnology. Microbiology and Molecular Biology Reviews, v. 63, n. 4, p. 735, 1999; PMID: 10585964

HORIKOSHI, K.; ANTRANIKIAN, G.; BULL, A. T.; ROBB, F. T.; STETTER, K. O. Extremophiles handbook. Berlin: Springer, 2011, v. 1-2. http://dx.doi.org/10.1007/978-4-431-53898-1

JAIN, D.; PANCHA, I.; MISHRA, S. K.; SHRIVASTAV, A.; MISHRA, S. Purification and characterization of haloalkaline thermoactive, solvent stable and SDS-induced protease from Bacillus sp.: A potential additive for laundry detergents. Bioresource Technology, v. 115, p. 228-236, 2012.

http://dx.doi.org/10.1016/j.biortech.2011.10.081

JAYAKUMAR, R.; JAYASHREE, S.; ANNAPURNA, B.; SESHADRI, S. Characterization of thermostable serine alkaline protease from an alkaliphilic strain Bacillus pumilus MCAS8 and its applications. Applied Biochemistry and Biotechnology, v. 168, p. 1849-1866, 2012. http://dx.doi.org/10.1007/s12010-012-9902-6

JELLOULI, K.; GHORBEL-BELLAAJ, O.; AYED, H.; MANNI, L.; AGREBI, R.; NASRI, M. Alkalineprotease from Bacillus licheniformis MP1: Purification, characterization and potential application as a detergent additive and for shrimp waste deproteinization. Process Biochemistry, v. 46, n. 6, p. 1248-1256, 2011. http://dx.doi.org/10.1016/j.procbio.2011.02.012

JOO, H. S.; KUMAR, C. G.; PARK, G. C.; PAIK, S. R.; CHANG, C. S. Oxidant and SDS stable alkaline protease from Bacillus clausii I-52: Production and some properties. Journal of Applied Microbiology, v. 95, n. 2, p. 267-272, 2003. http://dx.doi.org/10.1046/j.1365-2672.2003.01982.x

JOSHI, R. H. M. S.; DODIA, M. S.; SINGH, S. P. Production and Optimization of a Commercially Viable Alkaline Protease from a Haloalkaliphilic Bacterium. Biotechnology and Bioprocess Engineering, v. 13, p. 552-559, 2008. http://dx.doi.org/10.1007/s12257-007-0211-9

JOSHI, S.; SWATYANARAYANA, T. Characteristics and applications of a recombinant alkaline serine protease from a novel bacterium Bacillus lehensis. Bioresource Technology, v. 131, p. 76-85. 2013. http://dx.doi.org/10.1016/j.biortech.2012.12.124

KANEKAR, P. P.; NILEGAONKAR, S. S.; SARNAIK, S. S.; KELKAR, A. S. Optimization of protease activity of alkaliphilic bacteria isolated from an alkaline lake in India. Bioresource Technology, v. 85, p. 8793, 2002. http://dx.doi.org/10.1016/S0960-8524(02)00018-4

KUMAR, R.; ANANTHAN, G.; PRABHU, A. Optimization of medium composition for alkaline protease production by Marinobacter sp. GACAS9 using response surface methodology- A statistical approach. Biocatalysis and Agricultural Biotechnology, v. 3, p, 191-197, 2014. doi.org/10.1016/j.bcab.2013.11.005

KUNITZ, M. Crystalline soyabean trypsin inhibitor II. General properties. The Journal of general physiology, v. 30, p. 291-310, 1947. http://dx.doi.org/10.1085/jgp.30.4.311

http://dx.doi.org/10.1085/jgp.30.4.291 
LANE, D. 16S/23S rRNA sequencing. In: Nucleic acid techniques in bacterial systematic. STACKEBRANDT E.; GOODFELLOW, M (eds.). John Whiley, Sons: New York, 1991, p. 115-175.

LOWRY, O. H.; ROSEBROUGH, N. J.; FARR, A. L.; RANDALL, J. Protein measurement with the Folinphenol reagent. Journal of Biological Chemistry, v. 193, n. 1, p. 265-267, 1951.

MEENA, P.; TRIPATHI, A. D.; SRIVASTAVA, S. K.; JHA, A. Utilization of agro-industrial waste (wheat bran) for alkaline protease production by Pseudomonas aeruginosa in SSF using Taguchi (DOE) methodology. Biocatalysis and Agricultural Biotechnology, v. 2, p. 210 -216, 2013.

http://dx.doi.org/10.1016/j.bcab.2013.05.003

NADEEM, M.; QAZI, J. I.; BAIG, S.; SYED, Q. Studies on commercially important alkaline protease from Bacillus licheniformis N-2 isolated from decaying organic soil. Turkish Journal of Biochemistry, v. 32, p. 171-177, 2007.

NIELSEN, P.; FRITZ, D.; PRIEST, F. G. Phenitic diversity of alkaliphilic Bacillus strains: proposal for nine new species. Microbiology, v. 141, p. 1745-1746, 1995 .http://dx.doi.org/10.1099/13500872-141-7-1745

OSKOUIE, S. G.; TABANDEH, F.; YAKHCHALI, B.; EFTEKHAR, F. Response surface optimization of medium composition for alkaline protease production by Bacillus clausii. Biochemical Engineering Journal, v. 39, p. 37-42, 2008. http://dx.doi.org/10.1016/j.bej.2007.08.016

PATEL, R.; DODIA, M.; SINGH, S. P. Extracellular alkaline protease from a newly isolated haloalkaliphilic Bacillus sp.: Production and optimization. Process Biochemistry, v. 40, p. 3569-3575, 2005. http://dx.doi.org/10.1016/j.procbio.2005.03.049

PATEL, R. K.; DODIA, M. S.; JOSHI, R. H.; SINGH, S. P. Production of extracellular halo-alkaline protease from a newly isolated Haloalkaliphilic Bacillus sp. isolated from seawater in Western India. World Journal of Microbiology and Biotechnology, v. 22, p. 375-382, 2006. http://dx.doi.org/10.1007/s11274-005-9044-x

PHANSE, N.; RATHORE, P.; PATEL, B.; NAYARISSERI. A Characterization of an industrially important alkalophilic bacterium, Bacillus agaradhaerens strain nandiniphanse5. Journal of Pharmacy Research, v. 6, p. 543-550, 2013. http://dx.doi.org/10.1016/j.jopr.2013.04.035

RAJA, C. S.; PRABHAHAR, C. Screening and Optimization of Alkaline Protease Productivity from Bacillus sp. Agt from Tannery Effluent. International Journal of Pharmaceutical \& Biological Archives, v. 3, n. 1, p. 244-248, 2012.

SCHULEIN, M.; OUTTRUP, H.; JORGENSEN, P. L.; BJORNVAD, M. E. Alkaline xyloglucanases from Bacillus suitable for fabric detergents. PCT Int Appl. January 21, 1999. WO99o2663, Denmark.

SHAH, K.; MODY, K.; KESHRI, J.; JHA, B. Purification and characterization of a solvent, detergent and oxidizing agent tolerant protease from Bacillus cereus isolated from the Gulf of Khambhat Kunal. Journal of Molecular Catalysis B: Enzymatic, v. 67, p. 85-91, 2010. http://dx.doi.org/10.1016/j.molcatb.2010.07.010

SHIVANAND, P.; JAYARAMAN, G. Production of extracellular protease from halotolerant bacterium, Bacillus aquimaris strain VITP4 isolated from Kumta coast. Process Biochemistry, v. 44, p. 1088-1094, 2009. http://dx.doi.org/10.1016/j.procbio.2009.05.010

SMIBERT, R. M.; KRIEG, N. R. Phenotypic characterization. In: GERHARDT, P.; MURRAY, R. G. E.; WOOD, W. A.; KRIEG, N. R, editors. Methods for general and molecular bacteriology. Washington, DC: American Society for Microbiology, 1994. p. 607-54. 
SRIVIDYA, S.; MALA, M. Influence of process parameters on the production of detergent compatible alkaline protease by a newly isolated Bacillus sp. Y. Turkish Journal of Biology, v. 35, p. 177-182, 2011. http://dx.doi.org/10.3906/biy-0906-47.

SUNDARARAJAN, S.; KANNAN, C. N.; CHITTIBABU, S. Alkaline protease from Bacillus cereus VITSN04: Potential application as a dehairing agent. Journal of Bioscience and Bioengineering, v. 111, n. 2, p. 128-133, 2011. http://dx.doi.org/10.1016/j.jbiosc.2010.09.009

TAHER, A. G. Inland saline lakes of Wadi El Natrun depression. International Journal of Salt Lake Research, v. 8, n. 2, p. 149-170, 1999. http://dx.doi.org/10.1007/BF02442128

TANG, X. M.; LAKAY, F. M.; SHEN, W.; SHAO, W. L. L.; FANG, H. Y.; PRIOR, B. A.; WANG, X. Z.; ZHUGE, J. Purification and characterization of an alkaline protease used in tannery industry from Bacillus licheniformis. Biotechnology Letters, v. 26, p. 1421-1422, 2004 .http://dx.doi.org/10.1023/B:BILE.0000030042.91094.38 http://dx.doi.org/10.1023/B:BILE.0000045642.19299.3f

UYAR, F.; ILKNUR PORSUK, I.; KIZIL, G.; YILMAZ, E. I. Optimal conditions for production of extracellular protease from newly isolated Bacillus cereus strain CA15. EurAsian Journal of BioSciences, v. 5, p. 1-9, 2011. http://dx.doi.org/10.5053/ejobios.2011.5.0.1

VIJAYARAGHAVAN, P.; VINCENT, S. P. Cow dung as a novel, inexpensive substrate for the production of a halo-tolerant alkaline protease by Halomonas sp. PV1 for eco-friendly applications. Biochemical

Engineering Journal, v. 69, p. 57-60, 2012. http://dx.doi.org/10.1016/j.bej.2012.08.014

XU, F. March. Methods for using pectate lyases in baking. PCT Int Appl. 2000. WO0015038, United States. 